\title{
IAMJ
}

INTERNATIONAL

AYURVEDIC

MEDICAL JOURNAL

Review Article

ISSN: 2320-5091

Impact Factor: 6.719

\section{CRITICAL ANALYSIS OF NIDANA AND NIDANAPARIVARJANA IN HRIDROGA}

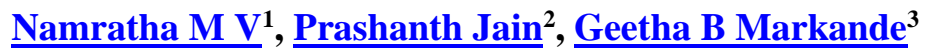 \\ ${ }^{1}$ II Year P.G Scholar, ${ }^{2}$ HOD, Professor, ${ }^{3}$ Associate Professor \\ Dept. of P.G Studies in Roganidana Evam Vikriti Vigyan, Alva's Ayurveda Medical College, Moodbidri, \\ Karnataka, India
}

Corresponding Author: namrathamv615@gmail.com

https://doi.org/10.46607/iamj2509092021

(Published Online: September 2021)

Open Access

(C) International Ayurvedic Medical Journal, India 2021

Article Received: 07/08//2021 - Peer Reviewed: 25/08/2021 - Accepted for Publication: 26/08/2021

Check for updates

\begin{abstract}
Ayurveda is the oldest medical science of human civilization which helps in preventing diseases and promoting health and longevity. Cardiovascular diseases are chronic disease pathology with acute manifestation and is a major cause of death in both the elderly and middle-aged. Nidana is the foremost component of Nidana Panchaka, which not only gives knowledge about causative factors of diseases but also helps in planning treatment protocol. Cardiovascular disorders as per Ayurveda can be studied under the spectrum of Hridroga. Over nourishment accompanied with physical inactivity leading to Santarpana state is well known to cause plethora of diseases like Hridroga. Consumption of food having mutual contradictory qualities results in morbid accumulation of Kapha and Meda in Raktamarga heralding Margavarana. It is said that the best treatment is Nidanaparivarjana i.e, to abstain from the causative factors. This paper deals with all the Nidanas of Hridroga and the importance of Nidanaparivarjana in preventing them.
\end{abstract}

Keywords: Hridroga, Cardiovascular diseases, Nidana, Nidanaparivarjana 


\section{INTRODUCTION}

Trimarmas are the basic authoritative organs that represent three distinct body systems: the nervous, cardiovascular, and urinary systems. Hridaya is classified as one of the Sadyapranahara marmas in Ayurveda and is the Moolasthana of Rasavaha srotas, Pranavaha srotas, and Asraya of Dasadhamanis. Prana and Vyana vata, Sadhaka pitta and Avalambaka kapha have their sthana, Hridaya. Multiple cardiovascular diseases as per Ayurveda can be studied under the spectrum of Hridroga. According to WHO cardiovascular diseases are the major causes of death globally, taking an estimated 17.9 million lives each year ${ }^{1}$. The incidence of lifestyle disorders like Hypertension, Diabetes mellitus, dyslipidemia and obesity associated with cardiovascular diseases is on rise. Changes in lifestyle and nutrition habits, a lack of physical activity, increased mental stress, and environmental changes are all increasing the risk of cardiovascular disease in today's world. Nidanas are the Vyadhi utpattikara bhavas which helps to know about the aetiology, symptomatology and pathogenesis ${ }^{2}$. It is one among the Upalabdhikarana of a disease ${ }^{3}$. According to Ayurveda the causes of Hridroga are classified into three and are Aharaja (dietary factors), Viharaja (lifestyle-related) and Manasika (psychological factors). Ayurveda is based on the concept of cure and prevention, and it is well applicable in the context of Hridroga. In order to prevent a disease, it is important to understand the causative factors. Nidanaparivarjana is one of the treatment protocols as per Ayurveda, is nothing but preventing disease by abstaining from exposure to causative factors. Understanding various risk factors of Hridroga is need of the hour.

\section{MATERIALS AND METHODS}

\section{Nidanas of Hridroga}

Acharyas enumerate several causative factors for Hridroga, and we may add Santarpanottha nidanas to the list, as they cause Srotolepa ${ }^{4}$, which is nothing more than Margavarana. So, according to the Samhitas, the causes of Hridroga may be classified as Apatarpanajanya nidana, Santarpanajanya nidana, Manasika nidana, and Iatrogenic factors.

\section{Apatarpanajanya Nidanas}

Atisevana of Ruksha, Sushka, and Tikta rasa, Alpabhojana, Upavasa, and Ativyayama are Apatarpana nidanas for Hridroga. These Nidanas will affect Snigdhata of Raktadhatu, owing to Vataprakopa and they will lead to Srotokharatwa (Coronary spasm). In modern environment, these Apatarpana nidanas will cause a shortage of fatty acids and antioxidants, which will increase the creation of cholesterol.

\section{Santarpanajanya Nidanas}

Santarpana nidanas include Atisnigdha bhojana, jeernabhojana, Guru- madhura- picchila aharas, $\mathrm{Na}$ vanna, Guda, Ksheera, Taila, Navamadhya ${ }^{5}$, Acheshtana and Nidra sukha etc. Excessive use of these will leads to the accumulation of circulating Meda in the Siras to Hridaya, which leads to Srotolepa and Dhamanipraticaya ${ }^{6}$. Madya is having properties like Ruksha, Ushna, Vikashi, Teekshna, Sukshma, Vyavayi and Vishada ${ }^{7}$. Atimadhya sevana will cause Raktadushti, Mamsavidahata and Medovaha srotodushti. It leads to Ojakshaya and thereby producing heart diseases because Hridaya is the Moola sthana for Ojas. According to contemporary science, chronic alcoholism leads to thymine deficiency, which acts as a cause for Wet beri beri heart disease i.e., Chronic cardiomyopathy.

\section{Viruddhahara Sevana}

When we are consuming mutually contradictory foodstuffs, for example, consumption of Chilichima Matsya along with Paya (milk), even though they are having Samana rasa i.e. Madhura rasa and Samana vipaka i.e. Madhura vipaka they are Veerya viruddha. This will act as Maha abhishyandi and will cause Sonita pradushana ${ }^{8}$. Thus, it ends up in Margoparodha and Hridroga.

\section{Vegadharana}

The suppression of Adharaneeya vegas will produce an impact on Hridya. 
Table 1:

\begin{tabular}{|l|l|}
\hline Vegas & Effect on heart \\
\hline Adhovata & Hridgada \\
\hline Mutra and Sakrut & Hridayasya uparodha \\
\hline Srama swasa and Bashpa & Hridroga \\
\hline Sukra and Pipasa & Hrid vyadha \\
\hline Hikka, Swasa and Udgara & Hrid vibandha \\
\hline
\end{tabular}

According to the modern view, this can be understood under the term Valsalva manoeuvre. Valsalva manoeuvre is the action of attempting to exhale with nostrils and mouth or glottis, closed. While this Valsalva manoeuvre there will be pressure rise inside the chest which leads to mild rise in blood pressure due to the forcing of blood out of the pulmonary circulation into the left atrium. The pressure inside the chest continues to rise. This will cause the return of systemic blood to the heart to be delayed. The heart's output is decreased, and blood pressure drops. With a rise in pressure, blood vessels contract reflexively. As a result, the pulse rate rises. Cardiac output began to rise as well. So, the pulse rate return to normal. The cardiovascular system of a healthy man withstands the intensive repeated straining at defaecation, compromised cardiovascular system may fail, resulting in syncope or even death. The increased pressure, tachycardia and reflex bradycardia can cause cardiac arrest in heart patients. The increased frequency and severity of straining for defecation or urination while holding the desire for Mutra or Sakrut will amplify the effect of the Valsalva manoeuvre and produce syncope.

\section{Manasika nidanas}

Acharyas have explained several manasika nidanas like Chinta, Bhaya and Trasa for Hridroga. Excess indulgence in these Nidanas will increase the Tamoguna. It will cause Kapha-Medodushti and accumulation of these in the rakta resulting in Shonita abhishyandana and Dhamani pratichaya. In modern science, it is explained that long term stress leads to high levels of cortisol which in turn causes an increase in the level of blood cholesterol, triglycerides, glucose, and blood pressure. All these will increase the risk of cardiovascular diseases.

\section{Iatrogenic factors}

Iatrogenic variables include chemotherapy-induced vascular events such as MI, arrhythmia, congestive heart failure, acute coronary events, thrombosis, and veno-occlusive disorders. Herbal drugs like vatsanabha, karaveera, ativisha if taken excessively in quantity produces Hridroga i.e. ativisha does vascular constriction and ahiphena does chyene- stroke breathing and tachycardia. Vamana and Virecana vyapats will produce Hridgraha ${ }^{9}$. In Basti, Hridprapti is a Vyapat $^{10}$. Hridshoola and Hridroga are produced by Ashuddha preparation of Abhraka bhasma, Loha bhasma, Vanga bhasma, Siddha makaradwaja, Rasa sindoor, Sameerapannaga rasa, and so on.

\section{RISK FACTORS}

Risk factors can be divided into 3 categories viz.- nonmodifiable risk factors, modifiable risk factors and emerging risk factors. Advanced age and genetic predisposition are non-modifiable risk factors. Smoking and alcohol use, sedentary lifestyle, hypertension, type II diabetes, dyslipidemia, obesity and metabolic syndrome are all modifiable risk factors.

\section{Emerging risk factors:}

Calcium supplementation: Aortic calcification is caused by long-term calcium supplementation, which increases the thickness of the carotid intima-media and raises the risk of coronary artery calcification.

Vitamin D deficiency: The mechanism by which Vitamin D improves CVD outcome is unknown; however, probable theories include downregulation of the renin-angiotensin-aldosterone system having direct effects on the heart and vasculature improvement of glycemic control. Vitamin D has a cardioprotective impact on the body. Vitamin D deficiency increases the chance of acquiring incident hypertension or sudden 
cardiac death in people who already have heart disease.

Anti-phospholipid syndrome (APS): Major cause of morbidity and mortality in the context of APS is a recurrence of thrombotic events. Experiments show evidence of an association between APS and premature formation of atherosclerotic plaque.

Premature birth/ Low birth weight: Studies shows that birth weight less than 6 pounds is associated with future cardiovascular diseases.

\section{NIDANAPARIVARJANA}

There are some lifestyle disorders where the core of the treatment is Utpatti hetum parihare ${ }^{11}$ i.e. abstain from the causative factors. In the case of heart diseases, we should avoid those causative factors which result in Shonita abhishyandana and Srotolepa. So, we should make a habit to include the ahara and vihara which are conducive for Hridaya. According to Bhavaprakasha nighantu, Godhuma, Piyusha, Rasala, Navaneeta, Vilapika, Sauvarchala lavana, Anupa jala, Alabu, Daadima, Kharjura, Naarikela, Maamsarasa, Edaka-lavaka mamsa, Shashkuli-shailendrya matsya, Purana madira are good for heart. Amra, Amrataka, Lakuca, Karamarda, Vrikshaamla, Amlavetasa, Kuvala, Badara, Dadima and Matulunga are the ten drugs which are cardiac tonic according to Acarya Caraka. These drugs are mainly Amlarasa pradhana and modern science proved that Vitamin $\mathrm{C}$ is cardioprotective in action. Vitamin $\mathrm{C}$ is having potent antioxidant properties and it will reduce LDL and increase HDL $^{12}$.

Viharas like optimum activities can be suggested to prevent heart disease. Regular practice of Yoga can relieve stress and anxiety thus lower the risk of cardiovascular diseases. Daily practice of Asanas like Paschimottasana, Pavanamuktasana, Shavasana, Gomukhasana and Ardhamatsyendryasana prevents the incidence of CVD. Meditations like Pranayama including Bhastrika, Kapalabandhi, Anulom- Vilom, Bhramari and Nadishodhana etc are beneficial.

\section{DISCUSSION}

The incidence of lifestyle disorders like hypertension, diabetes mellitus, dyslipidemia and obesity associated with cardiovascular diseases is on the rise. Various Ayurveda Samhitas have elaborately described Hridroga along with its Nidana, Samprapti, Lakshana and Chikitsa. Comparisons of different cardiac events explained in contemporary science with that of Ayurveda can be made mainly based on Lakshanas of different types of Hridroga. Management of cardiovascular events through Ayurveda can be done by accepting $\mathrm{Ni}$ danaparivarjana as the first step.

\section{CONCLUSION}

Viruddhahara, Santarpanottha ahara, Vega dharana, Cheshta dwesha and various Manasika nidanas are the leading factors predisposing cardiovascular diseases. As it is told in the classics "Nidana parivarjanameva chikitsta" one should abstain from all these Nidanas to prevent these diseases. Use of Ojasya, Hridya and Srotoprasadaka ahara- vihara are important line of treatment in Hridroga. To reduce the occurrence of cardiovascular diseases one should take a healthy diet, maintain a healthy weight, exercise regularly, keep levels of blood pressure and cholesterol under control, quit smoking, limit alcohol, and manage stress through Yogasanas and Pranayamas. The health of the heart is important through the health of the body. Leaving everything else, one should maintain the body. For if there is no body, there is nothing that can be made available to the individual ${ }^{13}$.

\section{REFERENCES}

1. https://www.who.int/health-topics/cardiovascular-diseases/\#: :text=Cardiovascular\%20diseases\%20(CVDs)\%20are\%20the, heart\%20disease $\% 20$ and $\% 20$ other\%20conditions.

2. Prof. Yadunandana Upadhyaya, Madhava Nidana of Sri Madhavakara with Madhukosha Sanskrit Commentary by Sri Vijayarakshita and Srikantadatta with Vidyotini Hindi Commentary and Notes by Sr Sudarshana Sastri, Part 1; Chapter 1, verse 5. Varanasi: Chaukambha Prakashan, 2013; p.18.

3. Dr Shivaprasad Sharma, Astanga Samgraha of Vagbhata or Vruddha Vagbhata with Sasilekha Sanskrit Commentary of Indu, Nidana Sthana; Chapter 1, Verse 8. Varanasi: Chaukhamba Sanskrit Series Office, 2008 ; p.352. 
4. Vaidya Jadavji Trikamji Acharya, Caraka Samhita by Agnivesa with Ayurveda Dipika Commentary of Cakrapanidatta, Sutra Sthana; Chapter 23, Verse 5-8. Varanasi: Chaukamba Krishnadas Aademy, 2010; p.122.

5. Vaidya Jadavji Trikamji Acharya, Caraka Samhita by Agnivesa with Ayurveda Dipika Commentary of Cakrapanidatta, Sutra Sthana; Chapter 23, Verse 3-4. Varanasi: Chaukamba Krishnadas Aademy, 2010; p.122.

6. Vaidya Jadavji Trikamji Acharya, Caraka Samhita by Agnivesa with Ayurveda Dipika Commentary of Cakrapanidatta, Sutra Sthana; Chapter 26, Verse 84. Varanasi: Chaukamba Krishnadas Aademy, 2010; p. 150 .

7. Pt. Hari Sadasiva Sastri Paradakara, Ashtangahrudaya of Vagbhata with Commentaries of Sarvangasundara of Arunadatta and Ayurvedarasayana of Hemadri, Nidana Sthana; Chapter 6, Verse 1. Varanasi: Chaukamba Sanskrit Sansthan, 2015; p.485.

8. Vaidya Jadavji Trikamji Acharya, Caraka Samhita by Agnivesa with Ayurveda Dipika Commentary of Cakrapanidatta, Sutra Sthana; Chapter 26, Verse 82. Varanasi: Chaukamba Krishnadas Aademy, 2010; p.149.

9. Vaidya Jadavji Trikamji Acharya, Caraka Samhita by Agnivesa with Ayurveda Dipika Commentary of Cakrapanidatta, Siddhi Sthana; Chapter 6, Verse 29-30. Varanasi: Chaukamba Krishnadas Aademy, 2010; p.705.

10. Vaidya Jadavji Trikamji Acharya, Caraka Samhita of Agnivesa with Ayurveda Dipika Commentary of Cakrapanidatta, Siddhi Sthana; Chapter 7, Verse 5. Varanasi: Chaukamba Krishnadas Aademy, 2010; p.709.

11. Vaidya Jadavji Trikamji Acharya, Susruta Samhita of Susruta with Nibandhasangraha Commentary of Sri Dalhanacharya and the Nyayachandrika Panjika of Sri Gayadasacharya on Nidanasthana, Sutra sthana; Chapter 15, verse 32. Varanasi: Chaukamba Sanskrit Sansthan; 2013, p.73.

12. Stuart Brody, Ragnar Preut, Kerstin Schommer Thomas H. Schurmeyer. A randomized controlled trial of high dose of ascorbic acid for reduction of blood pressure, cortisol, and subjective responses to psychological stress. Psychopharmacologia. 2002; 159(3): p.319-324.

13. Vaidya Jadavji Trikamji Acharya, Caraka Samhita by Agnivesa with Ayurveda Dipika Commentary of Cakrapanidatta, Nidana Sthana; Chapter 6, Verse 7.
Varanasi: Chaukamba Krishnadas Aademy, 2010; p. 220 .

\section{Source of Support: Nil Conflict of Interest: None Declared}

How to cite this URL: Namratha M V et al: Critical Analysis Of Nidana And Nidanaparivarjana In Hridroga. International Ayurvedic Medical Journal \{online\} 2021 \{cited September 2021\} Available from: http://www.iamj.in/posts/images/upload/2088_2092.pdf 